\title{
Genetic diversity of the Caribbean spiny lobster virus, Panulirus argus virus 1 (PaV1), and the discovery of PaV1 in lobster postlarvae
}

\author{
Jessica Moss ${ }^{1, *}$, Mark J. Butler IV ${ }^{2}$, Donald C. Behringer ${ }^{3}$, Jeffrey D. Shields ${ }^{1}$ \\ ${ }^{1}$ Department of Environmental and Aquatic Animal Health, Virginia Institute of Marine Science, Greate Road, \\ Gloucester Point, Virginia 23062, USA \\ ${ }^{2}$ Department of Biological Sciences, Old Dominion University, Norfolk, Virginia 23529, USA \\ ${ }^{3}$ School of Forest Resources and Conservation, Fisheries and Aquatic Sciences, University of Florida, Gainesville, \\ Florida 32653, USA
}

\begin{abstract}
Panulirus argus virus 1 (PaV1) is an unclassified, pathogenic virus first discovered in Caribbean spiny lobsters Panulirus argus from the Florida Keys, USA, and has since been confirmed in lobsters in other parts of the Caribbean. Several studies have examined the prevalence, pathogenicity, and population dynamics of the pathogen in the lobster host, but little is known about the genetic diversity of the virus. We analyzed a fragment of viral DNA from lobsters collected in the Florida Keys, which provided the first insight into the genetic diversity of PaV1. The variation in viral sequences, both within and between individual lobsters, indicates that lobsters can be infected with multiple viral strains. Laboratory experiments in which uninfected lobsters were serially exposed to lobsters inoculated with PaV1 implied that rapid mutation of strains is unlikely and suggest that there may be endemic strains of PaV1. In addition, we discovered PaV1 in $P$. argus postlarvae (pueruli), suggesting that the virus may disperse through the Caribbean within the long-lived ( 5 to $7 \mathrm{mo}$ ) planktonic phyllosoma larvae - a novel mechanism for dispersal of viruses in the sea.
\end{abstract}

KEY WORDS: Genetic variation $\cdot$ Pueruli $\cdot$ Vertical transmission

\section{INTRODUCTION}

Panulirus argus virus $1(\mathrm{PaV} 1)$ is a large, icosahedral virus that is pathogenic in the Caribbean spiny lobster Panulirus argus. Although as yet unclassified, PaV1 was first described in the Florida Keys, USA, in 1999 (Shields \& Behringer 2004). Infections have since been confirmed in Belize (Huchin-Mian et al. 2009), Mexico (Huchin-Mian et al. 2008), Cuba (Cruz Quintana et al. 2011), and the US Virgin Islands (Butler et al. 2008); thus, it is probably widespread in the Caribbean. The occurrence of disease has an ontogenetic component, with the highest prevalence and heaviest infections in early benthic juveniles (EBJs), and a re- duction in prevalence and intensity among the larger juveniles and adults (Shields \& Behringer 2004, Butler et al. 2008, Lozano-Álvarez et al. 2008). PaV1 prevalence in juvenile lobsters in Florida has ranged from 2 to $8 \%$, with some locations exceeding $40 \%$ (Behringer et al. 2011). Although adult lobsters are generally asymptomatic, they can be infected by PaV1, as has been determined through polymerase chain reaction (PCR) screening of adults in Florida (prevalence: $11 \%$ ) (Behringer et al. 2012), Belize (prevalence: $50 \%$ ) (Huchin Mian et al. 2009), and Cuba (prevalence: $4.48 \%$ ) (Cruz Quintana et al. 2011).

Heavily infected lobsters are typically lethargic, cease grooming and foraging, and have lower hemo- 
lymph serum protein values (Behringer et al. 2008). Juvenile and adult Caribbean spiny lobsters are usually social but this behavior is affected by infection with PaV1; in addition uninfected lobsters avoid diseased lobsters in the wild (Behringer et al. 2006).

Although the chalky-white appearance of infected hemolymph, viewed through the juncture of the abdomen and ventral carapace, has been used to diagnose PaV1 infections, it only reveals the most severely diseased individuals. More accurate diagnostic methods for PaV1 include histological analysis of preserved tissue sections, fluorescent in situ hybridization (Li et al. 2006), cell culture methods (Li \& Shields 2007), and a PCR assay (MontgomeryFullerton et al. 2007). The primers for the PCR assay amplify an approximately $500 \mathrm{bp}$ section of a $982 \mathrm{bp}$ viral fragment (GenBank accession no. EF206313) that appears to be an open reading frame (ORF) with no known homologs. Molecular detection of viral DNA using a PCR-based assay has been used to diagnose PaV1 in Panulirus argus from Florida (Behringer et al. 2012), Mexico (Huchin-Mian et al. 2008), Belize (Huchin-Mian et al. 2009), and Cuba (Cruz Quintana et al. 2011). For routine diagnosis of PaV1, we optimized the previously published PCR assay (Montgomery-Fullerton et al. 2007). During the optimization and validation of the modified PCR assay, sequencing of PaV1 isolates revealed inter-sequence nucleotide variation that had not been previously reported.

The objectives of the present study were to examine the sequence variation in PaV1 viral DNA from EBJ lobsters collected in the Florida Keys and postlarvae recruiting from offshore, and compare it with virus samples from juvenile lobsters used in laboratory disease challenges.

\section{MATERIALS AND METHODS}

\section{Postlarvae collection}

Transparent postlarvae (i.e. pueruli) of Panulirus argus were collected monthly using Witham-type artificial collectors (as in Butler \& Herrnkind 1991) moored at 2 locations in the nearshore Atlantic Ocean, within $0.5 \mathrm{~km}$ of Long Key, FL, USA (Fig. 1) from February to July 2007. Postlarvae arriving from the oceanic planktonic environment can be caught on these collectors around the time of the new moon (Acosta et al. 1997). The transparent postlarvae obtained from collectors were estimated to have been in the coastal waters for a few days at most, as they

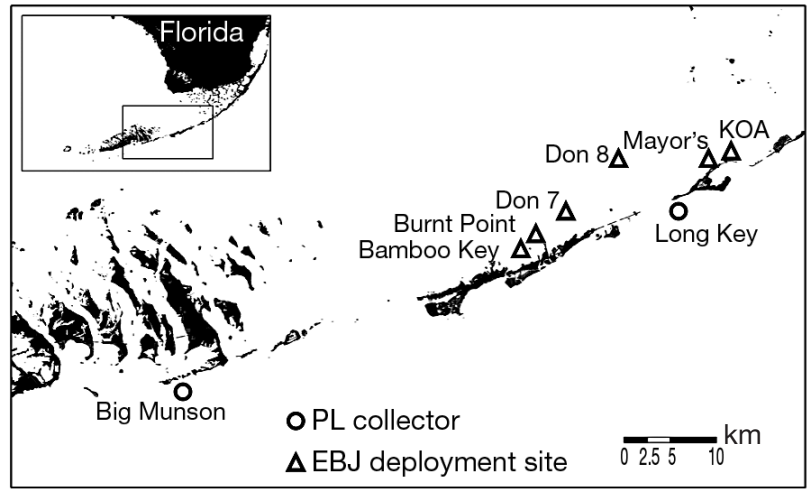

Fig. 1. Field sites in the Florida Keys, USA $\left(24.82^{\circ} \mathrm{N}, 80.82^{\circ} \mathrm{W}\right)$. EBJ: early benthic juveniles, PL: postlarvae

rapidly develop pigments upon settling in near-shore nursery habitats. After collection, postlarvae were frozen whole at $-20^{\circ} \mathrm{C}$ or $-80^{\circ} \mathrm{C}$ for PCR diagnostics.

\section{EBJ sentinel study}

EBJs were deployed as sentinels for PaV1 at 6 field sites in the Florida Keys in 2007. The sentinels were screened using PCR for the presence of PaV1 DNA only after deployment. The original purpose of the sentinel study was to determine the incidence of PaV1 in recently settled EBJs and young juveniles.

For the sentinel study, postlarvae were collected $7 \mathrm{~d}$ following the new moon from May to July 2007 from Witham-type collectors deployed oceanside of Long Key and Big Munson Key (Fig. 1) and held in re-circulating aquaria with UV-sterilized water for $<1$ wk until they metamorphosed into EBJs. EBJs were fed thawed brine shrimp and finely minced squid every other day. On the day of deployment, 1 or 3 EBJs were placed inside $0.25 \mathrm{~m}^{2}$ Vexar mesh cages (total of 30 to 50 EBJs per site) along with approximately $4 \mathrm{l}$ of their preferred settlement substrate, the red macroalgae Laurencia spp. (Herrnkind \& Butler 1986). The cages were then attached to the seafloor at 1.5 to $3 \mathrm{~m}$ depth at 6 hardbottom lobster nursery sites in the middle Florida Keys (Fig. 1). The cages were deployed for $2 \mathrm{wk}$ and then retrieved, and the remaining EBJs recovered and dissected; the tails were frozen individually in vials for later PCR diagnostics and the thoraxes were fixed and stored individually in $10 \%$ neutral buffered formalin for histology. For controls, we held 6 to 9 EBJs in the laboratory each month in individual $10 \mathrm{l}$ aquaria with UVsterilized flow-through seawater for the same time 
period as those deployed in the field. Control EBJs were processed for analysis as described for EBJs from the field.

\section{Viral mutation study}

Six hemolymph samples from a previous 'time-totransmission' experiment (see Behringer et al. 2006) were used to study the molecular variation of PaV1 in a laboratory setting. Specifically, we used the 6 samples to test whether the genetic variation we observed in viral isolates from individual lobsters was due to a high viral mutation rate after a single infection episode or whether viral variation within a lobster reflected multiple viral infections. In summary, 12 naive juvenile lobsters (20 to $35 \mathrm{~mm}$ carapace length) were inoculated with $50 \mu \mathrm{l}$ of PaV1infected hemolymph from a single donor and held individually in $10 \mathrm{l}$ aquaria supplied with UV-sterilized flow-through seawater for $2 \mathrm{wk} 4$ lobsters inoculated with hemolymph from a visibly uninfected donor collected from the wild and treated in the same manner served as controls. Hemolymph from the infected and uninfected donors was saved in sodiumcitrate lobster anticoagulant $(0.45 \mathrm{M} \mathrm{NaCl}, 0.1 \mathrm{M}$ glucose, $30 \mathrm{mM}$ sodium citrate, $26 \mathrm{mM}$ citric acid, 10 mM EDTA; pH 4.6 to 5.4; Söderhäll \& Smith 1983) and frozen at $-80^{\circ} \mathrm{C}$. At $2 \mathrm{wk}$ intervals over $8 \mathrm{wk}(4$ 'trials' total), a single naive lobster was held in each aquarium with one of the inoculated lobsters for $2 \mathrm{wk}$ (Fig. 2). Thus, 12 naive lobsters occupied separate aquaria, each with a lobster inoculated with PaV1infected hemolymph, while 4 other naive lobsters were held each with a control lobster inoculated with hemolymph from a naive lobster. After $2 \mathrm{wk}, 16$ more naive lobsters replaced those in aquaria in the previous exposure trial (12 with PaV1-infected lobsters, 4 with naive lobsters), and this procedure was repeated every $2 \mathrm{wk}$ for $8 \mathrm{wk}$.

At the end of each 2 wk exposure, the exposed lobsters were removed from the experimental aquaria and held in separate individual aquaria for approximately $80 \mathrm{~d}$ to allow for overt development of PaV1 infections. Initially, disease status during the experiment was assessed by examining the hemolymph of each lobster through the juncture of the carapace and abdomen. White hemolymph was indicative of viral infection. This was later confirmed in our laboratory using PCR. At the end of the holding period, all surviving animals were necropsied. Tissue samples from all lobsters, including the original PaV1 donor, the inoculated lobsters, and the exposed lobsters, were histologically processed. Hemolymph samples were drawn from all animals and the hemolymph frozen in anticoagulant at $-20^{\circ} \mathrm{C}$ or $-80^{\circ} \mathrm{C}$ prior to molecular diagnosis. The 6 hemolymph samples used to assess viral mutation included that from the donor and the 5 individuals that acquired the virus through exposure as seen in Behringer et al.'s (2006) Trial 4 (see 'Results - Viral mutation study').

\section{DNA extractions}

DNA extractions were performed on 100 to $150 \mu \mathrm{l}$ of lobster hemolymph, or on 100 to $150 \mathrm{mg}$ of lobster muscle tissue taken from the anterior portion of the tail of either postlarvae or EBJs. All extractions were carried out using a Qiagen DNeasy Blood and Tissue Kit following the manufacturer's protocol. Lobster genomic DNA was eluted in $150 \mu \mathrm{l}$ (hemolymph samples) or $200 \mu \mathrm{l}$ (tissue samples) of elution buffer and stored at $4^{\circ} \mathrm{C}$ until assayed.

The quality of genomic DNA was assessed by amplifying the small subunit ribosomal RNA (SSU rRNA) of the lobster using 'universal' SSU rRNA primers modified from Medlin et al. (1988) (see Moss et al. 2006). The amplified target DNA fragment was approximately $1800 \mathrm{bp}$ in length.

The diagnosis of PaV1 was done using the PCR primers published previously (Montgomery-Fuller-

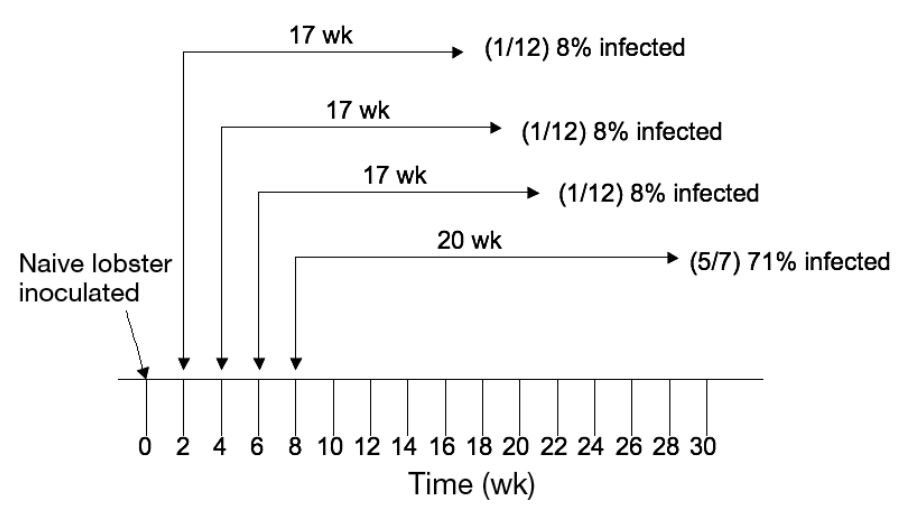

Fig. 2. Panulirus argus virus 1 (PaV1) infecting Panulirus argus. Experimental design of the PaV1 viral mutation study (redrawn from Behringer et al. 2006). At Time 0, 12 lobsters were inoculated with hemolymph from a single donor infected with PaV1. Trial 1: 2 wk after inoculation, 12 naive lobsters were exposed to the inoculated/infected lobsters for $2 \mathrm{wk}$. They were removed and held separately for $17 \mathrm{wk}$. Trials 2, 3, and 4, all at 2 wk intervals: more naive lobsters were exposed to the inoculated lobsters for $2 \mathrm{wk}$, removed, and maintained separately for 17 or $20 \mathrm{wk}$. The number and percentage of PaV1-positive (infected) lobsters after 17 or $20 \mathrm{wk}$ post exposure to inoculated lobsters are indicated 
ton et al. 2007), with modifications to reagent concentrations, thermocycling parameters, and reaction volume. The concentrations of the assay reagents were 1× PCR buffer (20 mM Tris-HCl [pH 8.4], $50 \mathrm{mM}$ $\mathrm{KCl}), 0.2 \mathrm{mg} \mathrm{ml}^{-1}$ bovine serum albumin (BSA), $1.5 \mathrm{mM} \mathrm{MgCl}_{2}, 0.2 \mathrm{mM}$ dNTPs, $0.5 \mu \mathrm{M}$ forward primer, $0.5 \mu \mathrm{M}$ reverse primer, and 1.0 unit Taq polymerase. Aliquots of $2.5 \mu$ l of lobster genomic DNA were added to $22.5 \mu$ l of PCR reagents for a final PCR volume of $25 \mu \mathrm{l}$. An additional control reaction containing $2.5 \mu \mathrm{l}$ of double-distilled water $\left(\mathrm{ddH}_{2} \mathrm{O}\right)$ plus $\mathrm{PCR}$ reagents in the above concentrations (no-DNA control) was included. The thermocycling parameters were an initial denaturation step at $94^{\circ} \mathrm{C}$ for $5 \mathrm{~min}$, followed by 40 cycles of $94^{\circ} \mathrm{C}$ for $45 \mathrm{~s}, 63^{\circ} \mathrm{C}$ for $45 \mathrm{~s}$, and $72^{\circ} \mathrm{C}$ for $1 \mathrm{~min}$, all followed by a final elongation step at $72^{\circ} \mathrm{C}$ for $10 \mathrm{~min}$. Aliquots of $10 \mu \mathrm{l}$ of PCR product were loaded onto a $2 \%$ agarose gel $(\mathrm{w} / \mathrm{v})$, electrophoresed at $100 \mathrm{~V}$, stained with ethidium bromide, and examined under UV light. Images were recorded using the Alpha Innotech FluorChem ${ }^{\circledR}$ imaging system. We determined the sensitivity of the modified PCR protocol to be $0.02 \mathrm{fg}^{-1}$ viral DNA or $0.05 \mathrm{fg}$ of viral DNA per PCR reaction using plasmid DNA of the viral sequence.

\section{Cloning and sequencing}

To assess the genetic variability of PaV1, a subset of PCR-positive samples were cloned and sequenced from naturally infected and laboratory-infected lobsters (see Table 1). PCR products of the correct size $(\sim 500 \mathrm{bp})$ were cloned into the plasmid $\mathrm{pCR}^{\circledR}{ }_{4-}$ TOPO and then transformed into Escherichia coli using a TOPO TA Cloning ${ }^{\circledR}$ Kit (Invitrogen) using half the manufacturer's volume recommendation of vector and chemically competent cells. Selection was based on ampicillin resistance. Transformed bacterial colonies were screened for inserts using a boilprep method followed by PCR amplification using the M13 vector primers (Moss et al. 2006). Before sequencing, PCR products were treated with shrimp alkaline phosphatase (SAP) and exonuclease I (ExoI) (Amersham Biosciences) to remove excess oligonucleotides and dNTPs. Bidirectional sequencing was performed using the Big Dye Terminator Kit v.3.1 (Applied Biosystems) with M13 sequencing primers in $5 \mu \mathrm{l}$ reactions with one-eighth the concentration of Big Dye recommended by the manufacturer's protocols. Sequencing reaction products were re-suspended in $20 \mu \mathrm{l}$ of $\mathrm{Hi}$-Di formamide (Applied Biosystems) and $10 \mu \mathrm{l}$ of each product were elec- trophoretically separated on an ABI 3130 Prism Genetic Analyzer.

Vector trimming and sequence editing were performed using CodonCode Aligner v. 3.0.3. Sequences were aligned using MacVector v. 8.1.2 and compared using Collapse v. 1.2 and Arlequin v. 2.0. TCS 1.21 was used to create a minimum spanning network of the observed viral alleles at the sequenced locus. FgenesV (http://linux1.softberry.com/), a trained pattern/Markov chain-based viral gene prediction program, was used to translate the sequenced region and to identify ORFs or possible viral genes.

\section{RESULTS}

\section{PaV1 detection by PCR}

Postlarvae

PaV1 DNA was detected in transparent postlarvae obtained from Witham collectors near Long Key in 3 of the 4 months sampled in 2007 (Table 1). Prevalence ranged from $30 \%$ in February to $0 \%$ in April. Transparent postlarvae arriving from offshore become pigmented within a day or two of settlement, thus our PCR results indicate that the postlarvae arrived from offshore with PaV1 infections.

\section{EBJs}

PaV1 DNA was detected in EBJs deployed as sentinels at all 6 field sites in the Florida Keys (Table 1). Prevalence of the virus ranged from $3 \%$ in the Bamboo Key samples to $71 \%$ in the Don 8 samples (see Fig. 1 for study sites), averaging $48 \%$. However, the sentinel study was flawed because PaV1 was prevalent in sentinel animals and controls (mean: 40\%; 2 -sample $t$-test: $t=0.415$, df $=7, \mathrm{p}=0.691$ ). Again, this indicates that a substantial portion of the postlarvae obtained from Witham plankton collectors and then deployed as sentinels or held individually in laboratory controls with UV-treated seawater were already infected with PaV1 when they arrived inshore. We could not determine whether EBJs caged as sentinels for 2 wk acquired additional infections.

\section{Viral mutation study}

Hemolymph samples were only analyzed by PCR in infected individuals (as determined histologically 
Table 1. Panulirus argus virus 1 (PaV1) infecting Panulirus argus. Postlarvae and early benthic juveniles (EBJs) were analyzed for the presence and prevalence (prev.) of PaV1 by PCR, and examined for viral diversity

\begin{tabular}{|c|c|c|c|c|c|c|c|c|}
\hline Site & $\begin{array}{l}\text { Collection } \\
\text { month }\end{array}$ & $\begin{array}{l}\text { No. ind. } \\
\text { collected }\end{array}$ & $\begin{array}{c}\text { No. PaV1- } \\
\text { positive by PCR }\end{array}$ & $\begin{array}{c}\text { PaV1 } \\
\text { prev. (\%) }\end{array}$ & $\begin{array}{c}\text { No. ind. } \\
\text { sequenced }\end{array}$ & $\begin{array}{l}\text { No. clones } \\
\text { sequenced }\end{array}$ & $\begin{array}{l}\text { No. alleles } \\
\text { observed }\end{array}$ & $\begin{array}{l}\text { Nucleotide } \\
\text { diversity }(\pi)\end{array}$ \\
\hline \multicolumn{9}{|c|}{ Transparent postlarvae obtained from Witham collectors } \\
\hline Long Key & Feb & 20 & 6 & 30 & 6 & 55 & 4 & 0.001854 \\
\hline Long Key & Mar & 20 & 1 & 5 & - & - & - & - \\
\hline Long Key & Apr & 20 & 0 & 0 & - & - & - & - \\
\hline Long Key & May & 20 & 4 & 20 & 4 & 38 & 5 & 0.019362 \\
\hline \multicolumn{9}{|c|}{ EBJs deployed as sentinels on nursery sites } \\
\hline Burnt Point & May & 30 & 18 & 60 & 4 & 38 & 4 & 0.002346 \\
\hline Bamboo Key & May & 30 & 1 & 3 & 1 & 11 & 2 & 0.002791 \\
\hline Don 7 & Jun & 40 & 28 & 70 & 4 & 32 & 4 & 0.007163 \\
\hline Don 8 & Jun & 51 & 36 & 71 & 4 & 34 & 4 & 0.010404 \\
\hline Mayor's & Jul & 35 & 15 & 43 & 4 & 33 & 8 & 0.014918 \\
\hline KOA & Jul & 37 & 16 & 43 & 4 & 37 & 5 & 0.011654 \\
\hline \multicolumn{9}{|c|}{ EBJs held in UV-treated seawater as sentinel controls } \\
\hline Lab controls & May & 7 & 0 & 0 & - & - & - & - \\
\hline Lab controls & Jun & 8 & 5 & 63 & 5 & 40 & 5 & 0.007296 \\
\hline Lab controls & Jul & 7 & 4 & 57 & 4 & 40 & 3 & 0.014228 \\
\hline
\end{tabular}

by Behringer et al. 2006) from the last exposure period in the time-to-transmission study (Trial 4). That is, naive lobsters were examined after their exposure for $2 \mathrm{wk}$ to lobsters inoculated $8 \mathrm{wk}$ earlier with infected hemolymph. All individuals determined to have PaV1 based on histology in Behringer et al.'s (2006) Trial $4(\mathrm{n}=5)$ were also positive for PaV1 DNA by PCR. The aliquot of frozen hemolymph from the original donor source of PaV1 for the experiment was also positive for PaV1 by PCR.

\section{Genetic analysis}

EBJs and postlarvae

Of the EBJ samples that were PCR-positive, 4 lobsters from each site, except Bamboo Key (only 1 positive sample), were cloned, and at least 8 clones from each site were bi-directionally sequenced. All of the EBJs used as controls for this study that were PCRpositive were also sequenced. Of the postlarvae that were PCR-positive from Long Key, viral DNA from all but one individual was cloned and at least 8 clones were sequenced (Table 1). Sequenced fragments of PaV1 ranged from 452 to $465 \mathrm{bp}$ in length (primer sequences removed). These sequences corresponded to bases 65 through 523/536 of the PaV1 sequence in GenBank (accession no. EF206313). When the software program FgenesV was used to translate the sequenced product, bases 145 to 465 (alignment posi- tion) could be translated into a possible viral gene of 105 amino acids in length.

Within the $\sim 500 \mathrm{bp}$ fragment of PaV1, there were 3 regions containing microsatellites and 10 major single nucleotide polymorphisms (SNPs) (Table 2). To limit the possibility of counting PCR error or sequencing misreads as SNPs, only those SNPs observed $>5$ times at a single locus within the data set were used in the analysis. We used 5 as the minimum number to establish a SNP as authentic because Taq error rates for PCR are estimated as $1.1 \times 10^{-4}$ base substitutions per base pair (Tindall \& Kunkel 1988), meaning that more than 3 or 4 errors at any single location would be highly unlikely. Of all the SNPs examined, only 3 appear to cause an amino-acid change. Those amino-

Table 2. Panulirus argus virus 1 (PaV1). Positions of PaV1 nucleotide variations. Bold: microsatellite sequences, with superscripts indicating the number of repeats observed. Nonbold: single nucleotide polymorphism (SNP), with the most common base observed listed first, followed by the observed base change. An asterisk $\left({ }^{*}\right)$ indicates those SNPs that caused an amino-acid change in the putative open reading frame

\begin{tabular}{|lccc|}
\hline Base position & Variation & Base position & Variation \\
\hline $10-33$ & (CGA) $^{\mathbf{4 - 8}}$ & 249 & $\mathrm{~A} / \mathrm{G}^{*}$ \\
70 & $\mathrm{C} / \mathrm{T}$ & 304 & $\mathrm{~A} / \mathrm{G}^{*}$ \\
$78-108$ & $\mathbf{( A C G )}^{\mathbf{6 - 1 0}}$ & 373 & $\mathrm{C} / \mathrm{T}$ \\
87 & $\mathrm{~A} / \mathrm{C}$ & 397 & $\mathrm{G} / \mathrm{A}$ \\
123 & $\mathrm{~A} / \mathrm{C}$ & 409 & $\mathrm{~T} / \mathrm{C}$ \\
$129-140$ & (CCG) $^{\mathbf{2 - 4}}$ & 436 & $\mathrm{C} / \mathrm{T}$ \\
234 & $\mathrm{~T} / C^{*}$ & & \\
\hline
\end{tabular}


acid changes were at base positions 234 (isoleucine/ valine), 249 (cysteine/arginine), and 304 (aspartic acid/glycine) (5'-3' notation with positions based on an alignment of all sequences with primers removed). Three microsatellites were observed; all were trinucleotide repeats (Table 2). Nucleotide diversity, calculated in Arlequin, ranged from the lowest in the postlarvae from the Long Key samples of February (0.001854) to the highest observed from the Long Key postlarval samples of May $(0.019362)$ (Table 1$)$.

Viral mutation study

There was little PaV1 sequence variation observed in the lobster inoculated with the donor PaV1 hemolymph at the start of the time-to-transmission experiment. Two alleles were present in the 8 clones analyzed from the PaV1 donor. One allele was found in 7 clones, while the other was observed only once. The dominant allele was compared to the 8 clones sequenced from the 5 lobsters infected with the virus in Trial 4 (40 sequences in total). Only 1 clone of the 40 clones was different from the dominant allele from the donor. The unique allele was not the rare allele seen in the donor; it either represents a mutation in the virus or a rare allele not initially identified when sequencing clones from the donor lobster. Note also that the naive lobsters exposed to the inoculated lobsters may have been naturally exposed to the virus; they were not pre-screened by PCR because the assay had not yet been developed, so it is possible that a small fraction of those allocated into the 4 trials could have already carried undetected low-level infections.

When the sequence data from the sentinel EBJs, postlarvae, and mutation experiment samples were combined, 33 alleles were identified (Table 3). By alleles, we mean unique sequences where all microsatellite and SNP regions were included. A minimum spanning network shows the genetic distance and relationships among alleles (Fig. 3). Specifically, this figure indicates the nucleotide differences between alleles, whether that is due to a microsatellite, or a SNP, or a combination of both. Representative sequences for each allele have been deposited in GenBank (accession nos. JN786952 to JN786984). Many of these alleles were found only once (i.e. in a single clone within a single individual lobster). When the singletons were removed from the data set, a total of 15 alleles remained. The most prevalent allele was 14, followed by alleles 9 and 3 (Table 3). The greatest number of viral alleles from a single group of lobsters were 8 from the EBJs deployed at the Mayor's site in
July. Most lobsters contained 1 or 2 viral alleles, although 6 individuals (5 EBJs and 1 postlarvae) had 3 alleles at the PaV1 locus; these combined data may be indicative of multiple infections of different viral strains.

Table 3. Panulirus argus virus 1 (PaV1) infecting Panulirus argus. Allele frequencies for PaV1 observed within each lobster sample. Bamboo Key, Burnt Point, Don 7, Don 8, KOA, and Mayor's: virus samples from early benthic juveniles (EBJs). LK: virus samples from postlarvae collected at Long Key. Lab controls: EBJs held under UV and served as controls for the sentinel study. VM: viral samples from juvenile lobsters sequenced as part of the viral mutation study

\begin{tabular}{|c|c|c|c|c|c|c|c|c|c|c|c|}
\hline$\frac{\stackrel{0}{d}}{\stackrel{4}{\varangle}}$ & 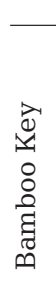 & 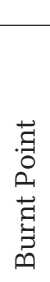 & $\begin{array}{l}\infty \\
\text { 몽 }\end{array}$ & $\begin{array}{l}\infty \\
\check{0} \\
\stackrel{0}{0}\end{array}$ & 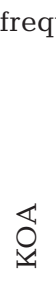 & 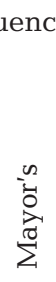 & $\begin{array}{l}0 \\
0 \\
0 \\
1 \\
y \\
y\end{array}$ & 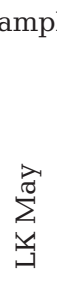 & 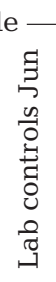 & $\begin{array}{l}3 \\
3 \\
0 \\
0 \\
0 \\
0 \\
0 \\
0 \\
0 \\
0 \\
0 \\
0\end{array}$ & 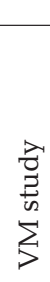 \\
\hline 1 & 10 & & & & & & & & & & \\
\hline 2 & 1 & & & & & & & & & & \\
\hline 3 & & 34 & 14 & 4 & & & & & & & \\
\hline 4 & & 2 & & & 1 & & & & 8 & & \\
\hline 5 & & 1 & & & & 7 & & & & & \\
\hline 6 & & 1 & & & & & & & & & \\
\hline 7 & & & 1 & & & & & & & & \\
\hline 8 & & & 1 & & & & & & & & \\
\hline 9 & & & 16 & 16 & 9 & 3 & & & 29 & & \\
\hline 10 & & & & 14 & & & & 8 & & & \\
\hline 11 & & & & 1 & & & & & & & \\
\hline 12 & & & & 1 & & & & 1 & & & \\
\hline 13 & & & & 1 & & & & & & & \\
\hline 14 & & & & & 23 & 8 & 50 & 9 & & 8 & \\
\hline 15 & & & & & 2 & & & & & & \\
\hline 16 & & & & & 1 & & & & & & \\
\hline 17 & & & & & & & 1 & & & & \\
\hline 18 & & & & & & & 1 & & & & \\
\hline 19 & & & & & & & 3 & & & & \\
\hline 20 & & & & & & & & 17 & & & \\
\hline 21 & & & & & & & & 1 & & & \\
\hline 22 & & & & & & 1 & & & & & \\
\hline 23 & & & & & & 7 & & & & & \\
\hline 24 & & & & & & 1 & & & & & \\
\hline 25 & & & & & & 1 & & & & & \\
\hline 26 & & & & & & 5 & & & & & 47 \\
\hline 27 & & & & & & & & & & & 1 \\
\hline 28 & & & & & & & & & & & 1 \\
\hline 29 & & & & & & & & & 1 & & \\
\hline 30 & & & & & & & & & 1 & & \\
\hline 31 & & & & & & & & & & 16 & \\
\hline 32 & & & & & & & & & 1 & & \\
\hline 33 & & & & & & & & & & 8 & \\
\hline Sum & 2 & 4 & 4 & 6 & 5 & 8 & 4 & 5 & 5 & 3 & 3 \\
\hline
\end{tabular}




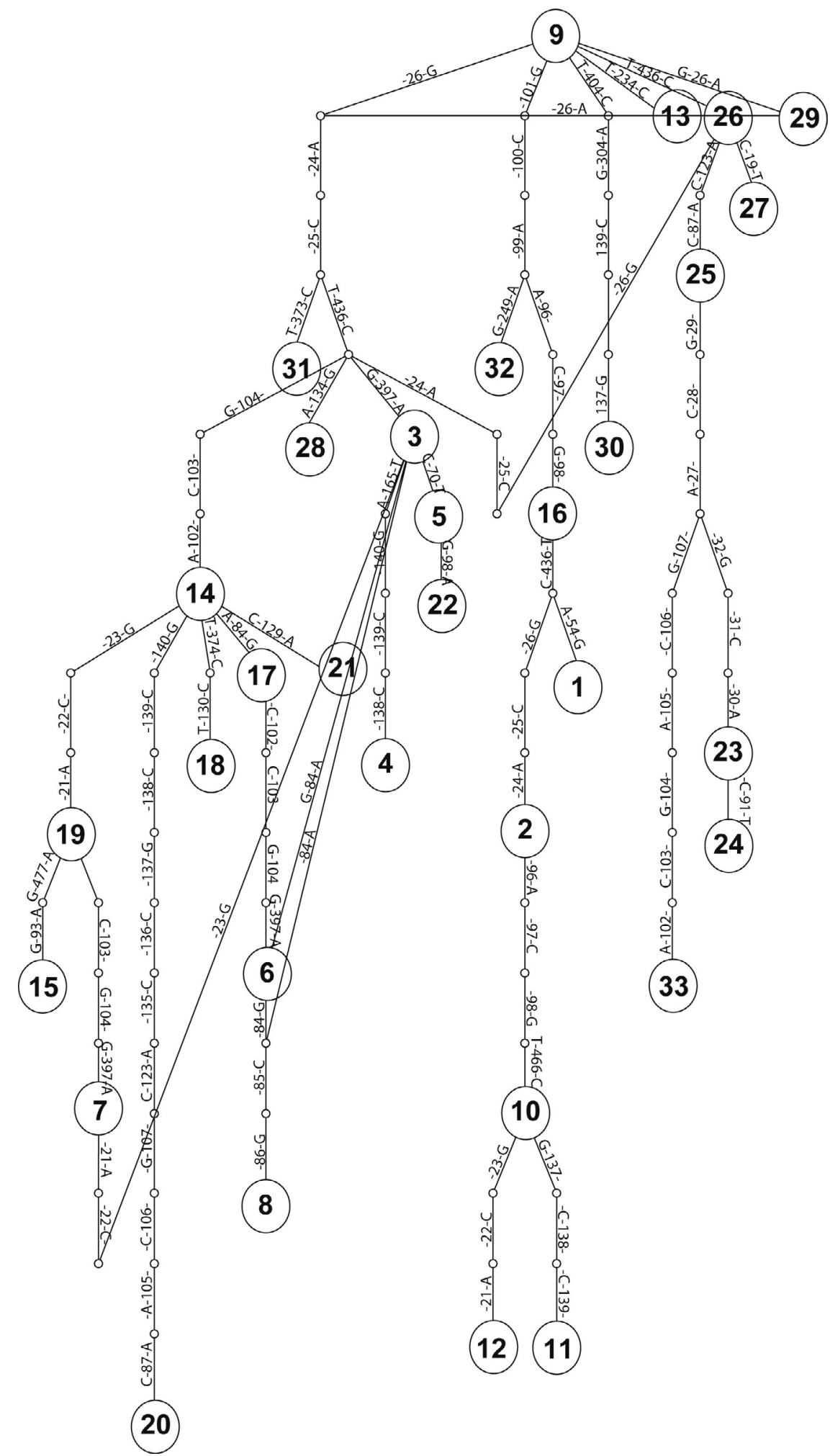

Fig. 3. Minimum-spanning network of viral alleles from Panulirus argus virus 1 (PaV1). Line length between alleles is directly proportional to the number of base-pair differences between alleles. Each segment along the lines represents a difference of 1 nucleotide. Specific base changes (location based on an alignment of the entire data set and base difference) are indicated between alleles

\section{DISCUSSION}

This study is the first to discover PaV1 in the planktonic postlarval stage of Panulirus argus, suggesting that larvae may play a role in the dispersal of the virus to new locations. Although we found no evidence of additional post-settlement infection of EBJs deployed as sentinels on the seafloor, the variation in viral sequences within and among lobsters suggests that they can be infected with multiple viral strains. Florida probably receives larvae from $P$. argus populations throughout the Caribbean, and we hypothesize that strain variation in PaV1 infecting postlarvae and EBJs may thus have a biogeographic basis. The results of our laboratory experiment testing for strain mutation in naive, serially exposed lobsters is consistent with the notion that there may be endemic strains of PaV1.

We also discovered a high DNA sequence variability in PaV1. When the PCR products from PaV1-positive postlarvae, EBJs, and juveniles were sequenced, a total of 33 unique alleles were observed. The DNA sequence variation is due to nucleotide differences at 3 microsatellite loci and 10 SNPs. The genetic diversity of PaV1 was surprisingly high for the viral genome region examined; however, sequence variation such as this, in the form of microsatellites or single point mutations is not novel. Relevant to crustaceans, extensive research exists on the variability of white spot syndrome virus (WSSV) in shrimp. Comparison of WSSV genomes from Thailand, Taiwan, and China has revealed that genome size varies due to the presence of several tandem repeats within the DNA sequence (van Hulten et al. 2001, Yang et al. 2001, Chen et al. 2002). The ORF 94 of WSSV from Thailand has 12 different sequence repeat groups (Wongteerasupaya et al. 2003). Variable number tandem repeat regions (VNTRs) (13 microsatellite and 3 mini-satellites) from a different region also have been reported for WSSV 
(Shekar et al. 2005), and variations in WSSV ORFs have proven useful as markers in epidemiological studies (e.g. Pradeep et al. 2008). Although we have only documented variability in a single locus of the PaV1 genome, the large number of alleles present at that locus indicates that the variability may be useful for epidemiological studies.

Genetic variation in viruses may also correspond to virulence differences in susceptible hosts. Pathogenicity differences between WSSV isolates are correlated with different genome sizes (Marks et al. 2005, Pradeep et al. 2009); viral isolates with the smallest genome size are more virulent and have increased fitness compared to isolates with larger genomes. Pradeep et al. (2009) reported that isolates with fewer VNTRs in specific ORFs had greater fitness, as determined by relative proportion among isolates when passaged through susceptible hosts. The role of microsatellites in the pathogenicity of PaV1 remains to be determined; however, given the high degree of variability, it seems possible that they could serve as markers for virulence or fitness attributes for the virus. The large amount of variability observed in the microsatellite lengths between isolates makes sense if this portion of the viral genome does not code for a gene, therefore allowing this region to accumulate mutations. Indeed, translation of the viral DNA into amino acids indicated that a portion of the $\sim 500 \mathrm{bp}$ fragment codes for 105 amino acids, with only 3 SNPs that cause aminoacid changes. The region that included the microsatellites does not appear to be within a coding region. Targeting this highly variable region may prove useful in future studies on the population genetics of this virus.

Analysis of samples from the mutation study confirms that the nucleotide variation in viral DNA within individual lobsters is not reflective of a rapidly mutating virus or portion of the virus, but instead reflects co-infection by a few stable viral strains. The duration of the transmission experiment was over 6 mo and most clones from the 5 individuals that acquired the virus via transmission from infected lobsters shared the same major allele found in the lobster whose PaV1-infected hemolymph was used as the donor for the experiment. This is in stark contrast to the allele diversity found in samples collected in the wild. For example, 8 different alleles were observed in just 4 EBJs deployed as sentinels at the Mayor's site.

We were unable to detect local PaV1 infection of EBJ lobsters beyond background levels of PaV1 prevalence in recruiting postlarvae. The EBJs we ob- tained as postlarvae from the plankton and deployed as sentinels for $2 \mathrm{wk}$ at 7 nursery sites had similar levels of infection as our laboratory-held controls. We attribute this to the episodic, but sometimes high, prevalence of PaV1 infection in postlarvae arriving from offshore, which we used as source animals for both sentinels and controls in our experiment. Yet, these results do not discount the potential for endemic post-settlement infection or sequential infection of lobsters, both of which appear likely based on laboratory infection studies.

It is unclear how the non-feeding postlarvae acquire the virus. The postlarvae were collected from Witham-type collectors on the ocean-side of the Florida Keys and therefore had no contact with juveniles that harbor PaV1 and which reside primarily in the shallow-water nursery on the gulf-side of the Florida Keys. Either the postlarvae were infected by PaV1 while in the plankton, or the virus was transmitted vertically to them from PaV1-infected parents.

Larval Panulirus argus have an extremely long planktonic phase of 5 to 7 mo (Goldstein et. al 2008) from the time they are spawned until they metamorphose tens of kilometers offshore into postlarvae that recruit inshore to shallow nursery grounds. Phyllosoma larvae are predators of smaller zooplankton and the PaV1 virus can be transmitted via ingestion in juvenile lobsters. So, it is plausible that PaV1 has an unknown secondary host in the plankton, although attempts to infect 3 other decapods (Menippe mercenaria, Mithrax spinosissimus, and the congeneric $P$. guttatus) with PaV1 through inoculation have been unsuccessful (Butler et al. 2008). We have demonstrated that waterborne transmission of PaV1 to EBJ lobsters is possible (Butler et al. 2008), so waterborne viruses could potentially infect larvae. PaV1 virions free-floating in the plankton are likely to be in dilute, perhaps non-infectious concentrations unless somehow concentrated as, for example, in marine aggregates (Lyons et al. 2005). However, PaV1 is an unenveloped virus that appears to only be viable in seawater for a few days (C. Li et al. unpubl. data), making waterborne transmission of PaV1 to larvae unlikely.

There are several examples of vertical transmission of viruses in crustaceans. Gill-associated virus (GAV) is transmitted from parent to progeny in the fertilized eggs and nauplii of the black tiger prawn Penaeus monodon, spawned from females and males positive for GAV (Cowley et al. 2002). Macrobrachium rosenbergii nodavirus (MrNV; the causative agent of white tail disease) and extra small virus (XSV) can be vertically transmitted (Sudhaka- 
ran et al. 2007). Rotifers naturally exposed to sediments with WSSV passed the virus to their eggs (Yan et al. 2004), and the virus appears to use vertical transmission in brine shrimp as well ( $\mathrm{Li}$ et al. 2003). Infectious hypodermal and hematopoietic necrosis virus (IHHNV) of shrimp uses vertical transmission in hosts that survive the acute stages of infection (Motte et al. 2003). We have confirmed the presence of PaV1 in egg-bearing female Panulirus argus (authors' unpubl. data) and are currently testing whether the virus can be vertically transmitted to eggs and larvae.

Whether larvae infected with PaV1 can move over the same distances as uninfected larvae remains to be determined, but finding infected postlarvae and infected egg-bearing adults opens the door to this possibility. Adult lobster populations throughout the Caribbean are isolated by distance and bathymetry, but these metapopulations are linked by the dispersal of planktonic larvae. Empirical evidence for longdistance dispersal of Panulirus argus larvae includes evidence that Brazilian P. argus westonii postlarvae occur occasionally in the waters off Florida (Sarver et al. 2000) and regular collections of $P$. argus in the Cape Verde Islands in the Eastern Atlantic, far from their Western Atlantic sources (Freitas \& Castro 2005). Moreover, analysis of mtDNA variation shows that there is no genetic structure of $P$. argus in the tropical and subtropical northwest Atlantic Ocean, consistent with high levels of gene flow among populations (Silberman et al. 1994).

The viral alleles of PaV1 may have utility as markers to demonstrate the connectivity of lobster populations in the Caribbean. Parentage analysis using microsatellite markers, for example, has been performed in a variety of marine species, including oysters (Xiao et al. 2011), clownfish (Planes et al. 2009), sunfish (MacKiewicz et al. 2002), and dolphins (Krützen et al. 2004). Recent investigations of genetic diversity and connectivity between Florida and Caribbean staghorn coral Acropora cervicornis found shared mtDNA haplotypes between the western Caribbean and Florida despite the fact that the planktonic larval duration of $A$. cervicornis is only about 4 d (Hemond \& Vollmer 2010). Potential sources of PaV1 to the Florida Keys include areas considered 'upstream' by current larval dispersal models (Butler et al. 2011). We are currently examining the biogeographic distribution of PaV1 alleles in the Caribbean to determine if PaV1 alleles can be used as biological 'tags' to test and validate simulation models of lobster dispersal, and hence population and disease connectivity in the Caribbean Sea.
Acknowledgements. We thank T. Matthews and J. Hunt (Florida Fish and Wildlife Conservation Commission) for providing postlarval lobster samples, T. Dolan and D. Parthree for assistance with GIS mapping, H. Small for helpful critique of the manuscript, K. Wheeler for technical assistance in the laboratory, and B. Barnes, D. Cook, J. Goldstein, M. Kintzing, J. Lear, M. Middlebrookes, A. Mojica, N. Osgood, and C. Stall who assisted with the field and laboratory experiments. We also appreciate logistical support provided by the Goshen Marine Laboratory. This work was funded by NSF grants OCE BE-UF 0723662, OCE0452805, and OCE 0929086. This is VIMS contribution \#3214.

\section{LITERATURE CITED}

Acosta CA, Matthews TR, Butler MJ (1997) Temporal patterns and transport processes in recruitment of spiny lobster, Panulirus argus, postlarvae to south Florida. Mar Biol 129:79-85

Behringer DC, Butler MJ, Shields JD (2006) Avoidance of disease by social lobsters. Nature 441:421

Behringer DC, Butler MJ IV, Shields JD (2008) Ecological and physiological effects of $\mathrm{PaV} 1$ on the Caribbean spiny lobster (Panulirus argus Latreille). J Exp Mar Biol Ecol 359:26-33

Behringer DC, Butler MJ IV, Shields JD, Moss J (2011) A review of Panulirus argus Virus 1 - a decade after its discovery. Dis Aquat Org 94:153-160

Behringer DC, Butler MJ IV, Moss J, Shields JD (2012) PaV1 infection in the Florida spiny lobster (Panulirus argus) fishery and its effects on trap function and disease transmission. Can J Fish Aquat Sci 69:136-144

Butler MJ IV, Herrnkind WF (1991) Effect of benthic microhabitat cues on the metamorphosis of pueruli of the spiny lobster Panulirus argus. J Crustac Biol 11:23-28

Butler MJ, Behringer DC, Shields JD (2008) Transmission of Panulirus argus virus $1(\mathrm{PaV} 1)$ and its effect on the survival of juvenile Caribbean spiny lobster. Dis Aquat Org 79:173-182

> Butler MJ IV, Paris CB, Goldstein JS, Matsuda H, Cowen RK (2011) Behavior constrains the dispersal of long-lived spiny lobster larvae. Mar Ecol Prog Ser 422:223-237

Chen LL, Leu JH, Huang CJ, Chou CM and others (2002) Identification of a nucleocapsid protein (VP35) gene of shrimp white spot syndrome virus and characterization of the motif important for targeting VP35 to the nuclei of transfected insect cells. Virology 293:44-53

Cowley JA, Hall MR, Cadogan LC, Spann KM, Walker PJ (2002) Vertical transmission of gill-associated virus (GAV) in the black tiger prawn Penaeus monodon. Dis Aquat Org 50:95-104

> Cruz Quintana Y, Rodríguez Canul R, Vidal Martinez V (2011) First evidence of Panulirus argus Virus 1 (PaV1) in spiny lobster from Cuba and clinical estimation of its prevalence. Dis Aquat Org 93:141-147

Freitas R, Castro M (2005) Occurrence of Panulirus argus (Latreille, 1804) (Decapoda, Palinuridae) in the northwest islands of the Cape Verde archipelago (central-east Atlantic). Crustaceana 78:1191-1201

- Goldstein JS, Matsuda H, Takenouchi T, Butler MJ IV (2008) A description of the complete development of larval Caribbean spiny lobster Panulirus argus (Latreille, 1804) in culture. J Crustac Biol 28:306-307

> Hemond EM, Vollmer SV (2010) Genetic diversity and con- 
nectivity in the threatened staghorn coral (Acropora cervicornis) in Florida. PLoS ONE 5:e8652

- Herrnkind WF, Butler MJ IV (1986) Factors regulating settlement and microhabitat use by juvenile spiny lobsters, Panulirus argus. Mar Ecol Prog Ser 34:23-30

Huchin-Mian JP, Rodríguez-Canul R, Arias-Bañuelos E, Simá-Álvarez R, Perez-Vega JA, Briones-Fourzán P, Lozano-Álvarez E (2008) Presence of Panulirus argus Virus 1 (PaV1) in juvenile spiny lobsters Panulirus argus from the Caribbean coast of Mexico. Dis Aquat Org 79: 153-156

> Huchin-Mian JP, Briones-Fourzán P, Simá-Álvarez R, CruzQuintana Y and others (2009) Detection of Panulirus argus Virus 1 (PaV1) in exported frozen tails of subadultadult Caribbean spiny lobsters Panulirus argus. Dis Aquat Org 86:159-162

Krützen M, Barre LM, Connor RC, Mann J, Sherwin B (2004) 'O father, where art thou?': paternity assessment in an open fission-fusion society of wild bottlenose dolphins (Tursiops sp.) in Shark Bay, Western Australia. Mol Ecol 13:1975-1990

Li C, Shields JD (2007) Primary culture of hemocytes from the Caribbean spiny lobster, Panulirus argus, and their susceptibility to Panulirus argus Virus 1 (PaV1). J Invertebr Pathol 94:48-55

Li C, Shields JD, Small HJ, Reece KS, Hartwig CL, Cooper RA, Ratzlaff RE (2006) Detection of Panulirus argus Virus 1 in the Caribbean spiny lobster using fluorescence in situ hybridization (FISH). Dis Aquat Org 72:185-192

Li Q, Zhang J, Chen Y, Yang F (2003) White spot syndrome virus (WSSV) infectivity for Artemia at different developmental stages. Dis Aquat Org 57:261-264

- Lozano-Álvarez E, Briones-Fourzán P, Ramírez-Estévez A, Placencia-Sánchez D, Huchin-Mian JP, Rodríguez-Canul R (2008) Prevalence of Panulirus argus Virus 1 (PaV1) and habitation patterns of healthy and diseased Caribbean spiny lobsters in shelter-limited habitats. Dis Aquat Org 80:95-104

Lyons MM, Ward JE, Smolowitz R, Uhlinger KR, Gast JR (2005) Lethal marine snow: pathogen of bivalve mollusc concealed in marine aggregates. Limnol Oceanogr 50: 1983-1988

MacKiewicz M, Fletcher DE, Wilkins SD, Dewoody JA, Avise JC (2002) A genetic assessment of parentage in a natural population of dollar sunfish (Lepomis marginatus) based on microsatellite markers. Mol Ecol 11:1877-1883

Marks H, van Duijse J, Zuidema D, van Hulten MC, Vlak JM (2005) Fitness and virulence of an ancestral white spot syndrome virus isolate from shrimp. Virus Res 110:9-20

- Medlin L, Elwood HJ, Stickel S, Sogin ML (1988) The characterization of enzymatically amplified eukaryotic 16Slike rRNA-coding proteins. Gene 71:491-499

> Montgomery-Fullerton MM, Cooper RA, Kauffman KM, Shields JD, Ratzlaff RE (2007) Detection of Panulirus argus virus 1 in Caribbean spiny lobsters. Dis Aquat Org 76:1-6

Moss JA, Burreson EM, Reece KS (2006) Advanced Perkinsus marinus infections in Crassostrea ariakensis maintained under laboratory conditions. J Shellfish Res 25:65-72
Motte E, Yugcha E, Luzardo J, Castro F and others (2003) Prevention of IHHNV vertical transmission in the white shrimp Litopenaeus vannamei. Aquaculture 219:57-70

Planes S, Jones GP, Thorrold SR (2009) Larval dispersal connects fish populations in a network of marine protected areas. Proc Natl Acad Sci USA 106:5693-5697

> Pradeep B, Shekar M, Gudkovs N, Karunasagar I, Karunasagar I (2008) Genotyping of white spot syndrome virus prevalent in shrimp farms of India. Dis Aquat Org 78: 189-198

Pradeep B, Karunasagar I, Karunasagar I (2009) Fitness and virulence of different strains of white spot syndrome virus. J Fish Dis 32:801-805

Sarver SJ, Freshwater DW, Walsh PJ (2000) The occurrence of the Brazilian subspecies of the spiny lobster (Panulirus argus westonii) in Florida waters. NOAA Fish Bull US 98: 870-873

Shekar M, Karunasagar I, Karunasagar I (2005) A computerbased identification of variable number tandem repeats in white spot syndrome virus. Curr Sci 89:882-887

Shields JD, Behringer DC Jr (2004) A new pathogenic virus in the Caribbean spiny lobster Panulirus argus from the Florida Keys. Dis Aquat Org 59:109-118

Silberman JD, Sarver SK, Walsh PJ (1994) Mitochondrial DNA variation and population structure in the spiny lobster Panulirus argus. Mar Biol 120:601-608

Söderhäll K, Smith VJ (1983) Separation of the haemocyte populations of Carcinus maenas and other marine decapods, and prophenoloxidase distribution. Dev Comp Immunol 7:229-239

Sudhakaran R, Ishaq Ahmed VP, Haribabu P, Mukherjee SC, Sri Widada J, Bonami JR, Sahul Hameed AS (2007) Experimental vertical transmission of Macrobrachium rosenbergii nodavirus (MrNV) and extra small virus (XSV) from brooders to progeny in Macrobrachium rosenbergii and Artemia. J Fish Dis 30:27-35

Tindall KR, Kunkel TA (1988) Fidelity of DNA synthesis by Thermus aquaticus DNA polymerase. Biochemistry 27: 6008-6013

> van Hulten MCW, Witteveldt J, Peters S, Kloosterboer N and others (2001) The white spot syndrome virus DNA genome sequence. Virology 286:7-22

> Wongteerasupaya C, Pungchai P, Withyachumnarkul B, Boonsaeng V, Panyim S, Flegel TW, Walker PJ (2003) High variation in repetitive DNA fragment length for white spot syndrome virus (WSSV) isolates in Thailand. Dis Aquat Org 54:253-257

Xiao J, Cordes JF, Moss J, Reece KS (2011) Genetic diversity in U.S. hatchery stocks of Crassostrea ariakensis (Fujita, 1913) and comparison with natural populations in Asia. J Shellfish Res 30:751-760

- Yan DC, Dong SL, Huang J, Yu XM, Feng MY, Liu XY (2004) White spot syndrome virus (WSSV) detected by PCR in rotifers and rotifer resting eggs from shrimp pond sediments. Dis Aquat Org 59:69-73

> Yang F, He J, Lin X, Li Q, Pan D, Zhang X, Xu X (2001) Complete genome sequence of the shrimp white spot bacilliform virus. J Virol 75:11811-11820

Submitted: June 20, 2011; Accepted: November 23, 2011 Proofs received from author(s): February 1, 2012
Editorial responsibility: Hans Heinrich Janssen, Oldendorf/Luhe, Germany 